\title{
春柱靫帯細胞の微細構造
}

$\begin{array}{cccccc}\text { 山口大学整形外科 } & & & \\ \text { 木 } & \text { 戸 } & \text { 健 } & \text { 司・河 } & \text { 合 伸 也 } \\ \text { 小 } & \text { 田 } & \text { 裕 } & \text { 胤・土 } & \text { 井 } & \text { 一 輝 } \\ \text { 田 } & \text { 中 } & & \text { 浩・石 } \text { 田 } \text { 洋一郎 } \\ \text { 峯 } & & \text { 孝 } & \text { 友 } & & \end{array}$

\section{Microscopic Structure of Cultured Human Ligament Cells}

by

Kenji Kido, Shinya Kawai, Hirotsugu Oda,

Kazuteru Doi, Hiroshi Tanaka, Yoichiro Ishida and Takatomo Mine

Department of Orthopedic Surgery,

Yamaguchi University School of Medicine, Yamaguchi, Japan

The cause of the ossification of human spinal ligament is still not clear. The purpose of this paper is to report morphological features of cultured cells of the human spinal ligaments by means of scanning and transmission electron microscopy.

In light microscopic studies, spindle shaped cells (fibroblast-like cell) formed some colonies in dish after 7-10 days cultivation.

In electron microscopic studies, cultured cells have relatively smooth cell surface (S.E. M.), well developed rough E.R., and a nucleus of low electrical density (T.E.M.).

These cultured cells resemble to fibroblast in electron microscopic studies.

\section{緒}

\section{言}

春柱勒帯骨化の発生機序については，様々な方面か らの研究がなされているが，その詳細については，今 なお不明な点が多い.

当大学では, 一つのアプローチとして, 脊柱勒帯を 構成する細胞に対し, 細胞培養を行なっており, 骨化 例，非骨化例の培養細胞の形態的・生化学的性質の間 に，若干の差異か認められることを報告してきた ${ }^{11,21}$. 今回は非骨化例の培養細胞に対し, 細胞培養の過程 で，䩲帯の細胞成分の中で，いかなる細胞が培養され てくるかを同定することを目的として，走査型及び透 過型電子顕微鏡による観察を行なったので報告する.

\section{方}

\section{法}

ヒト脊柱靶帯の細胞培養の方法は, 石田等の方法に て行ない, 電子顕微鏡による観察は, 第 1 回維代培養 の際, carbon coating を施した, cover glass の上 に培養し，細胞增殖後，in situ に固定，脱水を行ない， TEM は一旦, cover glass の上で Epon にて包埋 後, 液体窒素にて急速冷却し, 細胞を cover glass より剝離した後, 再包埋, 薄切した. SEM は, cover glass 上で臨界点乾燥法にて乾燥後，金パラジゥム蒸 着を施した。

\section{結果}

而柱勒带培養細胞は, 細胞播種後約 $3 \sim 7$ 日目に plating を開始し，播種後10日目には dish 上に 3 ない し 4 個の colony を形成し，更に增殖した．培養細胞 はいずれも紡鍾形の胞体と，その中心部に核を持ち， 各種背柱勒帯を通して，その形態に明らかな差異は認め なかった. colony 形成後も，この形態に明らかな変化 は認めなかったが，それぞれの細胞間の関係は colony の各部位により, 若干の差異が認められた. colony の周辺部では, 紡鍾形の細胞が散在し, 細胞 間に連絡は認められないが, colony の中間部では, 


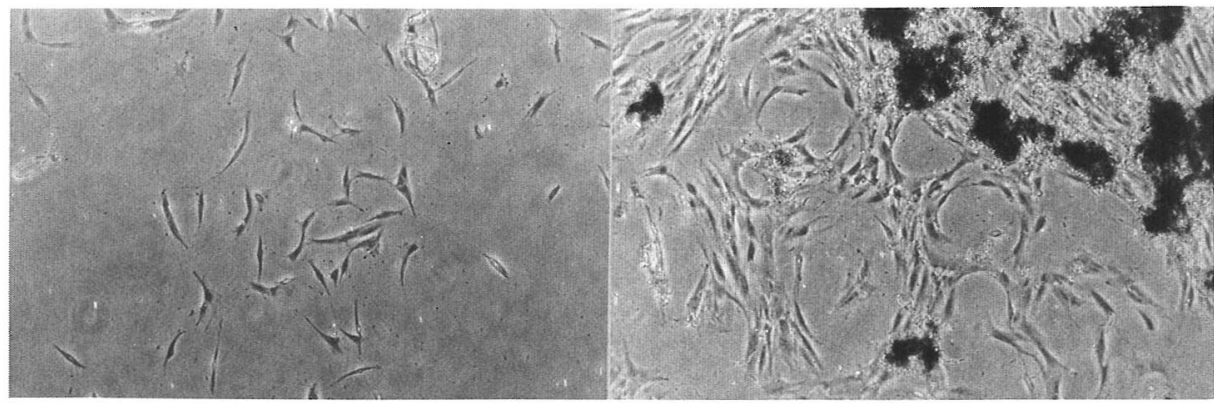

辺縁部

中間部

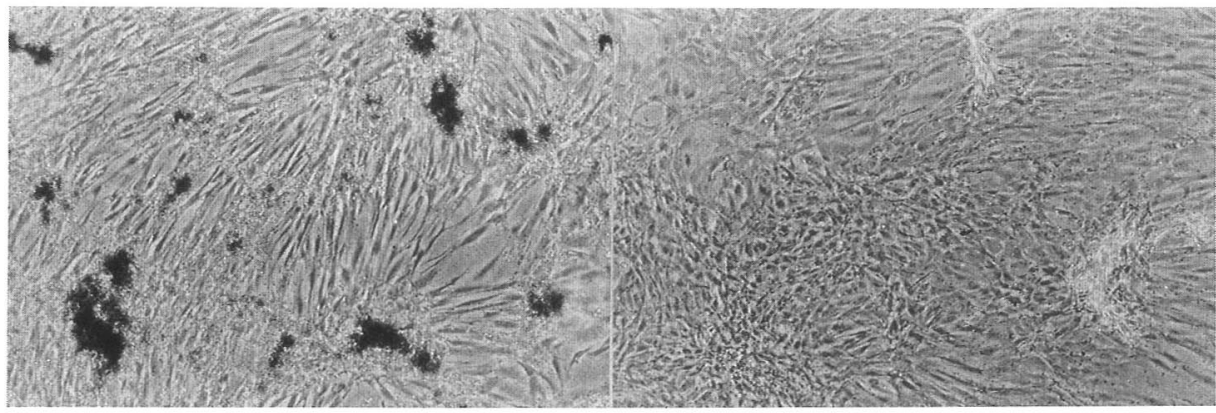

中間部

中心部

図 1 cultured lig. cells

colony の各部位において, 細胞の基本的形態に差異は無いが, 細胞間 の関係には若干の相違を認める.

(E.M.)

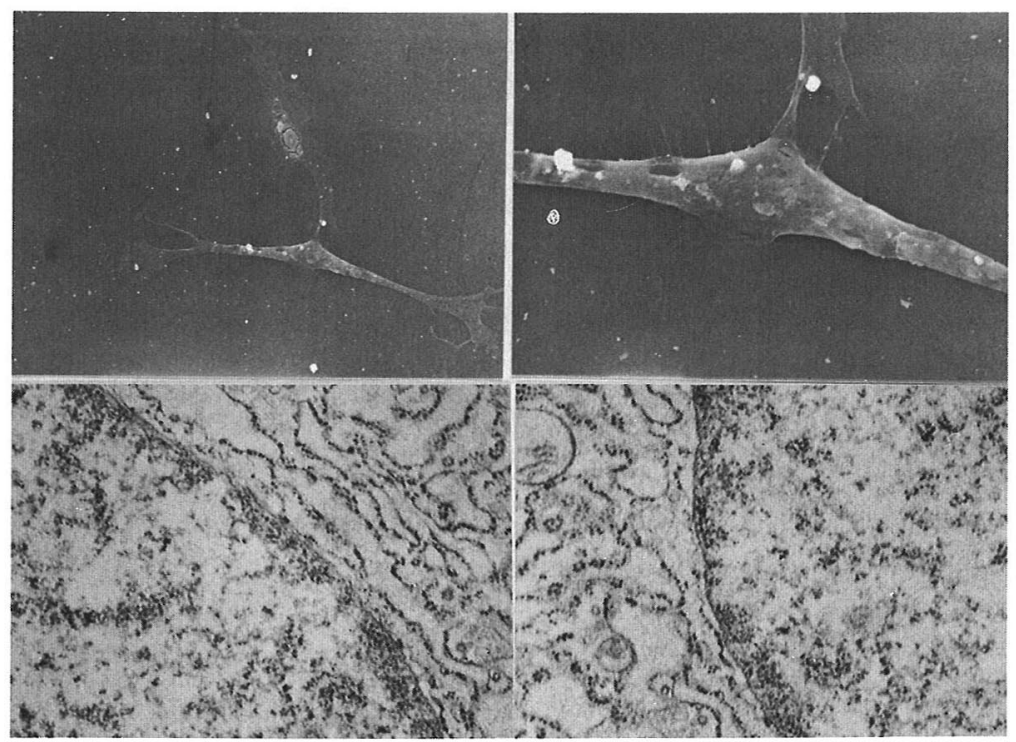

図 2 Cultured lig. cells

SEM では細胞の表面は比較的平滑で，TEM では良く発達した細胞 内小器官を認める. 
数個の細胞が集まり，管腔状の形態をとったり，一定 の方向に走行するようになる. colony の中心部では, 細胞の一部は重層化し, 細胞突起の長さは減少し, 多 角形に近い細胞も認めるようになる。（図 1 )

SEM）培養細胞は，扁平で紡錘形の胞体を有するこ とは，位相差顕微鏡での観察と同一であるが，細胞の 表面は比較的平滑で，一部には 2 つの細胞が, 細い細 胞突起によって，連結されている像も認められる.

TEM）培養細胞は電子密度の低い淡明な核と, 豊富 な粗面小胞体を有する細胞質を持ち，粗面小胞体の中 には一部内腔が囊状に拡大しているものも認められ， 活発な細胞分泌能を示している.（図2）

\section{考察}

脊柱䩲帯骨化の成因については，これまでに行なわ れた各種の研究により，全身的骨化素因としての内分 泌，ホルモン異常，遺伝的素因，又局所因子としての 春柱䩲帯に加わる力学的負荷の関与の可能性が示唆さ れてきている゙!. これに対する隹柱勒帯の構造的変化と しては, 主としてその細胞外成分である膠原線維, 弾 性線維等の線維成分に対し観察がなされ，その走行の 乱れ，線維の断裂等が示されてきた.しかし最近では, 骨形成能の関点から細胞成分の研究もすすみ, 骨化に 先立つ未分化間葉系細胞の増殖による靶帯の肥厚, 骨 化部先端での軟骨様細胞の増殖に伴なう，軟骨性基質 の分泌等の報告がみられる.

細胞培養による研究は, これら靶帯内細胞成分の, 生化学的特徴を明らかにするうえで, 有用な方法であ ると考えられるが, 培養の過程で, 細胞の周囲基質と の関係が失なわれる点や, 形態にも若干の変化がみら れる点より, 培養細胞が細胞成分の中のいかなる細胞 から主として構成されているかを知ることは重要なこ とと考えられる.

今回得られた培養細胞は, 光学顕微鏡的には, 紡錘 形の胞体と密接な細胞間の関係を持ち, SEM による 観察では，比較的平滑な細胞表面を有していた，TEM による観察では，電子密度の低い淡明な核を持ち，細 胞質は良く発達した粗面小胞体に富んでいた。これら の像からは, 明らかな線維成分の分泌等は不明だ， 培養細胞は細胞活性に富み, 正常靶帯の細胞成分の主 なものである線維芽細胞によく類似した細胞であると 考えられた。

\section{結}

論

1. ヒト背柱勒帯に対して細胞培養を行ない, 走査 型，透過型電子顕微鏡による観察を行なった。

2. 鞁帯培養細胞は $3 \sim 4$ 日で plating を開始し, 播種10日後には plate 内に数個の colony を形成した. colony の各部位において, 細胞間の関係に若干の差異 が認められた.

3 ．䩲帯培養細胞は，SEM による観察では，比較 的平滑な細胞表面を持ち，TEM では電子密度の低い 核と，小胞体等の細胞内小器官に富む細胞質を有して おり，線維芽細胞に類似した細胞と思われた。

\section{参 考 文 献}

1）石田洋一郎他：後縦靸帯骨化の細胞培養における検 討, 厚生省特定疾患脊柱䩲帯骨化症調査研究班昭和 62 年度研究報告書, 42-44.

2）石田洋一郎他：ヒト脊柱靫帯より得られた培養細胞 に関する基礎的研究. 日本整形外科学会雑誌, $62: \mathrm{S}$. $145,1987$.

3）斉鹿稔：背柱後縦靶帯骨化の形態からみた成因およ び進展に関する検討. 日本整形外科学会雑誌, $61 ： P$. 1059-1072, 1987.

\section{発 言琉球大学 乗松 尋道}

靶帯骨化を起こすには細胞の変化以外に微細環境の 変化がなければならないと考えます．特に骨誘導回 の作用が重要ではないかと考えます．今後御検討下さ い.

質 問州大学 馬渡 正明

(1)あえて in vitro で研究する理由.

(2)先生の示された細胞は fibroblast だと思いますが, 他の部位の fibroblast との形態上の差異があるのか.
解 答 山口大学 木戸 健司

(1)各種の負荷実験（ホルモン等）が可能である為. (2)本実験のみで fibroblast と同定することは困難である.

閶 久留米大学 小宮 節郎 ALP 染色で培養細胞を検索されておられますか.

解 答山大学 木戸 健司

まだ行なっておりません. 